\title{
KACPER KARDAS
}

Uniwersytet Śląski, Katowice

\section{Nowy słownik polsko-łaciński. Propozycje założeń}

\author{
Od wielu lat odczuwamy brak słownika polsko-łacińskiego, \\ który by odpowiadał dzisiejszym wymaganiom [...]
}

(Niemiec 1946: 235).

Powyższe słowa Rudolf Niemiec wypowiedział podczas odczytu pt. „Praca nad nowym słownikiem polsko-łacińskim”, który odbył się w trakcie zebrania Komisji Filologicznej Polskiej Akademii Umiejętności kilka miesięcy po zakończeniu II wojny światowej (listopad 1945 r.). Po zapoznaniu się z ofertą opracowań polsko-łacińskich na współczesnym rynku możemy powiedzieć, że mimo upływu prawie 70 lat słowa te niewiele straciły na znaczeniu. Współczesny użytkownik, który chciałby dokonać konsultacji podczas przekładu czy to w zakresie słowa, frazy, czy też pełnego zdania, poza internetowymi słownikami i komputerowymi tłumaczami, nieposiadającymi na ogół fachowej weryfikacji (np. pl.glosbe.com, Google Translate), ma do dyspozycji głównie niewielkiej wartości nieduże wydawnictwa komercyjne, zwykle łączone w ramach edycji z równie mało użytecznymi zbiorami łacińsko-polskich par słów, które — jeżeli postawić je na tle całej polskiej leksykografii latynistycznej (zob. Plezia 2001) — zdają się nieco na wyrost pretendować do miana słowników. Dla przekładu leksyki ogólnej obecnie szerzej funkcjonują w Polsce tylko dwa pełniejsze, samodzielne opracowania, na których ostatecznie można by jako tako polegać — niestety obydwa posiadają pewne dotkliwe dla użytkownika braki. Pierwszym z nich jest znany ze swej niebieskiej okładki, wielokrotnie wznawiany przez wydawnictwo PWN „Mały słownik polsko-łaciński” (Winniczuk (red.) 1994, ostatnie dostępne wydanie to ${ }^{132011), ~ k t o ́ r e g o ~ o s z c z e ̨ d n o s ́ c ́ ~}$ w podawaniu informacji dotyczących ekwiwalentów oraz wyraźna skłonność autorów do neologizowania sprawia, że jego zastosowanie w praktyce jest zawężone właściwie tylko do rozwiązywania szkolnych ćwiczeń. Drugim opracowaniem jest zaś „Słownik polsko-łaciński” A. Bielikowicza (1863-1866), dostępny ogółowi dzięki obecności w zdygitalizowanej formie w zasobie Repozytorium Cyfrowego Instytutów Naukowych (rcin.org.pl/publication/1917). Na jego anachroniczność wskazywał we wspomnianym 
referacie już R. Niemiec (1946: 236), metaleksykografowi z początku XXI w. nietrudno wskazać cechy, które utrudniają, a w każdym razie czynią mocno niekomfortowym korzystanie zeń także dziś' ${ }^{1}$.

W przeszłości polskiej leksykografii łacińskiej rozwiązywano podobny problem braku dostępności odpowiedniego słownika trojako (por. Plezia 2001):

1) poprzez przedruk słowników opracowanych wcześniej (np. Koncewicz ${ }^{9} 1929$, Węclewski ${ }^{3} 1927$ );

2) poprzez adaptację na grunt polski opracowania obcego (np. Kruczkiewicz (red.) 1907 - Stowasser 1894, Kopia 1926 - Menge 1903);

3) poprzez przygotowanie opracowania zupełnie nowego, najczęściej w oparciu o inne słowniki (np. Plezia (red.) 1959-1979, Korpanty (red.) 2001-2003).

W sytuacji, w jakiej znajdujemy się obecnie, najlepsze wydaje się rozwiązanie, które zostało podane jako ostatnie. $Z$ jednej strony przemawia za tym fakt, że w polskiej leksykografii języków klasycznych mieliśmy stosunkowo niedawno dowód, że można przygotować od podstaw dobry słownik, którego językiem wejścia jest polszczyzna (Abramowiczówna, Appel 2006). Z drugiej zaś zauważyć należy, że stan współczesnej wiedzy metaleksykograficznej pozwala na wykreowanie opracowania nowoczesnego, czerpiącego to co najlepsze tak z neofilologicznego słownikarstwa przekładowego, jak i z tradycji leksykografii latynistycznej, co jeszcze kilkadziesiąt lat temu byłoby zapewne nieosiągalne. Postulat nowoczesności jest w przypadku słownika polsko-łacińskiego o tyle ważny, że jako opracowanie par excellence aktywne, tj. służące do kodowania tekstu, jest on w leksykograficznej klasie słowników łacińskich ewenementem i w związku z tym należy podchodzić do jego tworzenia ze szczególną ostrożnością. Poniższy tekst ma na celu ogólne zarysowanie możliwego kształtu takiego opracowania oraz wskazanie pewnych makrostrukturalnych rozwiązań, które mogłyby nadać mu pożądany, nowoczesny charakter.

Trzeba zdawać sobie sprawę z tego, komu tworzony słownik ma służyć i do czego ma służyć

(Stańczak 2007: 111).

Jest to tylko jeden z szeregu głosów, które podkreślają, że punktem wyjścia refleksji nad koncepcją jakiegokolwiek nowoczesnego opracowania słownikowego powinno być zdefiniowanie jego docelowego użytkownika (por. także np. Dubois, Dubois 1971: 18, Linde-Usiekniewicz 2011: 108-109, a szczególnie Bańko 1994: 21, 2001: 13), najlepiej w oparciu o przesłanki pozostające w związku z rzeczywistością, nie zaś tylko wizję obecną w głowie leksykografa (por. Piotrowski 1994: 78). Inaczej niż w przypadku

\footnotetext{
${ }^{1}$ Są to m.in. ciągła, niezróżnicowana a przez to słabo czytelna typografia, archaiczna ze współczesnego punktu widzenia ortografia (por. pisownię instytucya, ztąd) oraz inne nieobecne dziś formy językowe (fleksyjne, np. kmiecy, w dalszém znaczeniu, leksykalne, np. chapnać, dotleć, godziciel, gotość, kondolować, także semantyczne, np. kryminalista w znaczeniu 'znawca prawa karnego'), brak rozbudowanego aparatu mikrostrukturalnego.
} 
neofilologów (np. Tomaszczyk 1979, Lew 2004) i polonistów (Żmigrodzki, Nowak, Ulitzka 2005) wśród środowisk związanych z językami klasycznymi nie przeprowadza się ankiet dotyczących korzystania z opracowań słownikowych, nie mówiąc już o szerszych badaniach, wychodzących ku potencjalnym „zewnętrznym” użytkownikom. Badania takie z pewnością warto podjąć w przyszłości, jednakże w obecnym stanie rzeczy piszący te słowa czuje się rozgrzeszony z tego, że naświetlając poniżej najczęstsze cele konsultacji słownikowej w kierunku język polski-łacina, korzysta wyłącznie $\mathrm{z}$ własnego doświadczenia tłumacza tekstów obu języków.

Obserwacja zatem wskazuje, że do słownika polsko-łacińskiego sięga się, gdy zachodzi potrzeba dokonania:

a) przekładu tekstu przeznaczonego do interpretacji publicznej (np. inskrypcje nowołacińskie, łacińskojęzyczne szyldy, dyplomy);

b) przekładu tekstu na użytek prywatny (tatuaże, sentencje, frazy grawerowane na biżuterii itp.);

c) konsultacji leksykalnej przy układaniu komunikatu w języku łacińskim (tzw. „żywa łacina");

d) konsultacji leksykalnej przy prowadzeniu badań językoznawczych (np. porównawczych);

e) wprowadzenia do tekstu polskiego nietradycyjnego wtrętu lub onimizowanej łacińskiej jednostki leksykalnej;

f) przekładu ćwiczeniowego na potrzeby kursu językowego (na poziomie szkoły średniej lub studiów wyższych) lub samodzielnej nauki języka.

Przypadki osób zasięgających konsultacji w słowniku zebrane we wszystkich tych grupach należy traktować jako potencjalnych odbiorców słownika, a także, jeśli zwracać uwagę na komercyjny aspekt leksykograficznych prac, jego ewentualnych nabywców. Głównym zatem, choć nie jedynym celem konsultacji jest zazwyczaj przekład określonego tekstu, stąd też i samo opracowanie powinno ciążyć ku przekładowemu charakterowi. Powyższy podział właściwie można zawęzić do dwóch tylko rodzajów użytkowników: (1) wykwalifikowanych oraz (2) nieprzygotowanych językowo. Idealne opracowanie powinno uwzględniać potrzeby, które są udziałem przedstawicieli obydwu grup. Postulat ten, rzecz jasna, kłóci się z głosami specjalistów-metaleksykografów przekonujących, że ,słownik dla wszystkich w istocie nie jest słownikiem dla nikogo" (por. Bańko 1994: 22, 2001: 13, Piotrowski 1994: 65), jednakże w sytuacji, gdy rynek nie zachwyca bogactwem (por. także inne uzasadnienia, jakie podaje Linde-Usiekniewicz 2011: 110), warto poszukać „złotego środka”, który pozwoli korzystać ze słownika zarówno profesjonalistom, potrzebującym bardziej dokładnych informacji o ekwiwalentach, jak i amatorom, poprzestającym z reguły na samych translatach².

Zasadnicze znaczenie dla makrostruktury słownika polsko-łacińskiego ma fakt, że jeden z języków jego pary przekładowej posiada ilościowo stały — jeżeli nie liczyć

${ }^{2}$ Być może właściwym wyjściem w takiej sytuacji byłoby wprowadzenie odpowiednich rozwiązań (np. typograficznych) na poziomie mikrostruktury słownika, które pozwolą na odróżnienie w pierwszym spojrzeniu informacji ,podstawowych” od „zaawansowanych”. 
drobnych zmian spowodowanych zdobyczami na polu krytyki tekstów — leksykon, który pod względem rozwoju semantycznego pozostaje w chwili obecnej statyczny. Nie ma w przypadku łaciny mowy o takiej elastyczności, jaką cechuje leksykograficzne sprzęganie słownictwa polskiego z leksemami języków żywych. Gdy dołożyć do tego niepełną izomorficzność, jaka zawsze występuje między dwoma językami (Linde-Usiekniewicz 2011: 120), okaże się, że nie można wykorzystać przy tworzeniu słownika najprostszego leksykograficznego rozwiązania, jakie się nasuwa, czyli wytyczenia w oparciu o któreś z istniejących opracowań polszczyzny ogólnej indeksu haseł, który w dalszej kolejności uzupełniany byłby ekwiwalentami łacińskimi i dodatkowymi informacjami stylistycznymi, pragmatycznymi itp. Zacząć należy niejako na opak: od przygotowania listy opisanych odpowiednio translatów, którym w procesie układania słownika przyporządkowywane byłyby najbardziej zbliżone semantycznie ekwiwalenty polskie. Jeżeli okaże się to niezbędne, w dalszej kolejności można uzupełnić przygotowany powyżej zbiór o te polskie jednostki, których nie da się w łacinie oddać inaczej niż opisowo. Zupełnie natomiast należy się wystrzegać wprowadzania w roli ekwiwalentów neologizmów, tj. słów oraz konstrukcji, które nie są notowane w żadnym z „,rejestrów” 3 języka łacińskiego, ale zostały niejako ,na siłę" stworzone przez leksykografa dla oddania danego słowa. Zakłamywałoby to obraz leksyki łacińskiej oraz utrudniałoby skuteczne tworzenie funkcjonalnych (zrozumiałych) łacińskich komunikatów.

Nie da się przewidzieć pełnego spektrum fraz, jakie z zastosowaniem słownika będą przekładane; mogą to być zarówno twierdzenia o wysokim poziomie abstrakcji (np. milość ci wszystko wybaczy), jak i takie, które zmierzają do przekazania komunikatu opartego o kategorie konkretne (np. w samochodzie pękła opona). W związku z tym zakres czasowy i stylistyczny słownictwa, które znajdzie się na jego kartach, powinien być jak najszerszy: trzon zbioru haseł powinny stanowić, rzecz jasna, słowa i znaczenia obecne w łacinie klasycznej, jednakże obok nich powinny się także znaleźć jednostki zaczerpnięte z leksykonu łaciny późnoantycznej, średniowiecznej (np. zwyczajowa tytulatura urzędowa lub kościelna) oraz wyrazy będące w użyciu wśród współczesnych żywołacinników. Przy czym raczej powinny to być wyrazy z warstwy ogólnej języka aniżeli terminy z wyspecjalizowanym, wąskim osadzeniem dziedzinowym (np. terminy medyczne lub botaniczne) ${ }^{4}$. Ponieważ zatem będą się znajdować w słowniku jednostki z różnych dzieł, czasów, kręgów tematycznych itp., niezbędne będzie wprowadzenie do jego mikrostruktury systemu lokalizatorów, które zapobiegną zlaniu się przedstawianego materiału w homogeniczną masę. Bez niego użytkownik nie będzie w stanie odróżnić od siebie ekwiwalentów różnej proweniencji, zaś nieczytelność ta sprawi, że słownik wiele straci na swojej użyteczności. Liczne fakty językowe

${ }^{3}$ Przez to określenie należy rozumieć zbiór utrwalonych w piśmie, posegregowanych chronologicznie świadectw, które składają się na udokumentowaną całość istnienia języka łacińskiego czy to jako języka posiadającego użytkowników natywnych, czy też przekazywanego „sztucznie”.

${ }^{4}$ Ominięcie tego rodzaju słownictwa nie odbędzie się zresztą ze szkodą dla użytkownika, ponieważ istnieje wiele opracowań specjalistycznych, które uzupełniałyby postulowany słownik w tym aspekcie (np. Babecki, Dąbrowska 1978, Dąbrowska 1990; zob. więcej w: Wojan 2013). 
i pozajęzykowe ${ }^{5}$ przemawiają za tym, by przy podawaniu lokalizacji ekwiwalentów nie ograniczać się do wskazywania ogólnego zakresu czasowego stosowania danego kompleksu „wyraz-znaczenie”, lecz w tych przypadkach, gdzie ma to szczególną wagę, osadzać w skróconej formie nazwisko autora, dla którego określone użycie jest charakterystyczne. Rozwinięcie skrótów powinno, rzecz jasna, pojawić się w odrębnej partii, gdzie użytkownik znaleźć będzie mógł również najważniejsze informacje na temat danego twórcy czy dzieła (np. czas tworzenia/powstania czy przynależność do odmiany języka).

Obecność w słowniku takiej części uzasadnienia dalszego nie wymaga, podobnie jak za oczywistą uznać należy dla słownika partię, w której przedstawione zostaną cele i założenia redakcyjne opracowania. Ze względu na jego specyfikę należy się jednak zastanowić nad wprowadzeniem co najmniej kilku dodatkowych, nie-leksykalnych partii, które sprawią, że stanie się narzędziem bardziej uniwersalnym, wygodnym w użyt$\mathrm{ku}$, a co najważniejsze, możliwym do skutecznego stosowania nawet dla tych, którzy z jakichś powodów potrzebują łacińskiego przekładu tekstu, a nie posiadają rozległej kompetencji w zakresie łaciny. W tradycji neofilologicznego słownikarstwa przekładowego każdy słownik otwierany jest przez zestaw prawideł wymowy i ortografii obcego dla docelowego użytkownika języka z pary przekładowej, następnie krótko przedstawiane są jego zasady gramatyczne. W leksykografii latynistycznej zwyczaj ten nie jest kultywowany, zapewne dlatego że dydaktyka języków klasycznych dysponuje nader rozbudowanym aparatem osobno wydawanych gramatyk rozmaitego sortu i objętości, w których wszystkie te informacje są zawarte. Nie ma jednak powodów, by niewolniczo trzymać się tej konwencji - wręcz przeciwnie, zamieszczenie stosownych wskazówek prozodycznych oraz skróconego wykładu fleksji, składni i słowotwórstwa łacińskiego przyniesie użytkownikowi korzyści, gdyż nie będzie musiał się zaopatrywać w dodatkowe opracowania, by w pełni móc ze słownika korzystać6.

Proponowany słownik powinien mieć charakter opracowania wspomagającego użytkownika w procesie tłumaczenia tekstu z języka polskiego na łacinę. Andrzej Bogusławski, autor instrukcji budowania dwujęzycznych słowników przekładowych, poprzez „tłumaczenie tekstów” rozumie:

podstawianie wyrażenia języka translatów na miejsce wyrażenia translandów odpowiednie dla danej sytuacji, tzn. podstawianie takiego wyrażenia, jakie jest najbardziej naturalne dla rodzimych użytkowników języka translandów w danej sytuacji (Bogusławski 1988: 22).

Analogiczną myśl znajdujemy m.in. u teoretyka przekładu, E.A. Nidy, który w swojej definicji przekładowej ekwiwalencji dynamicznej podaje, że skonstruowane z jej użyciem tłumaczenie to: „najbliższy naturalny ekwiwalent komunikatu przekazanego w języku źródłowym" (Nida 2009: 64).

${ }^{5}$ Na przykład autorski charakter wielu starożytnych znaczeń leksemów łacińskich, częściowe zregionalizowanie łaciny średniowiecznej, brak jednej instytucji wyznaczającej kształt nowołacińskiego słownictwa.

${ }^{6}$ Nietrudno znaleźć przykłady wskazujące, że zebranie tego, co w materii gramatyki łacińskiej najważniejsze, nie musi się odbyć kosztem wielkiego nakładu miejsca (zob. B a ro n 1991). 
Opinii pozostających w związku z tym tematem można by przytoczyć o wiele więcej (np. Piotrowski 1989), pozostańmy jednak przy tych dwu. W obu przypadkach to, co wyrażone zostało poprzez „odpowiedniość wyrażeń” i „naturalność komunikatu”, sprowadza się do określenia celu przekładu, który ma wywołać w użytkowniku języka tłumaczenia dokładnie taką samą reakcję, jaką w paralelnym odbiorcy wzbudza tekst źródłowy. Reakcja ta powinna być identyczna na wszystkich poziomach kompetencji językowej. Gdy mówi się o przekładzie ogólnie, najłatwiej wskazać, że musi ona zostać zachowana w warstwie gramatycznej i leksykalnej tekstu, jednak kiedy stykamy się bezpośrednio z niewłaściwie przełożonym tekstem, pierwszym aspektem, który rzuca się w oczy, jest jego warstwa stylistyczna. Zarówno Nida, jak i Bogusławski odkładają kwestię izomorfii stylistyki źródła i przekładu nieco na bok, koncentrując się na ekwiwalencji tych dwóch poziomów języka, które wymienione zostały jako pierwsze. Źródeł takiego zwrócenia zainteresowań szukać należy zapewne w tym, że obydwaj badacze skupiają się na zjawiskach, które pozostają udziałem języków współczesnych, żywych, używanych w bezpośredniej komunikacji. Lecz casus łaciny jest inny: odległość czasowa i odmienność kulturowa, jaka dzieli języki łaciński i polski, oraz rzeczywistość, w której każdy z nich jest osadzony, nie pozwala postawić znaku równości, a jedynie chwiejną tyldę podobieństwa pomiędzy stylistyką wypowiedzi polskiej i łacińskiej. Dlatego też rację ma R. Niemiec, kiedy mówi, że: „sam słownik nie wystarczy, by pisać dobrze po łacinie" (1946: 236). Warto rozwinąć ideę tego zdania, wprowadzając do słownika partię, która obejmowałaby podstawowe wskazówki niezbędne do właściwego kompozycyjnie konstruowania łacińskich zdań. Lecz wbrew zamysłowi Niemca, który, jak wolno sądzić, miał na myśli zamieszczenie wytycznych wyłącznie dla pisania w łacinie klasycznej, część ta nie powinna sprowadzać się do charakterystyki stylu obowiązującego tylko w jednym okresie ewolucji języka łacińskiego, ale tych wszystkich, których słownictwo znajdzie się w części leksykalnej. Więcej: poza uwagami stylistycznymi powinny się tam znaleźć również elementy opisu ogólnego, tak by nawet nieobeznany z historią łaciny użytkownik słownika mógł w podstawowym zakresie przyswoić sobie te kategorie, które filolodzy klasyczni pojmują intuicyjnie (np. łacina średniowieczna). Oczywiście, nie da się w niewielu słowach tak poinstruować użytkownika, by pisał on po łacinie jak Katon Starszy, Tacyt czy Kadłubek, jednakże nawet lichy okruch wiedzy w materii kompozycji z pewnością będzie dla niego lepszy aniżeli całkowite pozostawienie go w tej kwestii samemu sobie.

W leksykonie każdego języka — a polszczyzna nie jest wyjątkiem — znajdują się takie jednostki, których z samej ich natury ,,przełożyć” w pełnym znaczeniu tego słowa się nie da, jako że warstwy znaczeniowej nie posiadają. Mowa tu, rzecz jasna, o nazwach własnych, które, jak przyjmuje się wśród językoznawców, na ogół pełnią funkcję wyłącznie referencyjną, własnego znaczenia nie posiadając czy to przez fakt, że były go pozbawione od początku swego istnienia, czy ponieważ ich pierwotna motywacja semantyczna zatarła się z upływem czasu. Nie ulega wątpliwości, że zamieszczenie w słowniku haseł tego typu (zwłaszcza nazw miejscowych i osobowych) będzie kolejnym korzystnym dla użytkownika posunięciem, atoli generowałoby dwa konieczne do 
poniesienia problemy: po pierwsze, mianowicie, zauważmy, że o ile bodaj wszystkie tradycyjnie używane w Polsce imiona posiadają swoje ugruntowane odpowiedniki łacińskie, o tyle w przypadku np. toponimów nie zawsze tak bywa. Wydaje się, że optymalnym rozwiązaniem będzie tutaj podążanie ścieżką przyjętą przy włączaniu w listę haseł leksemów słownictwa pospolitego - do słownika powinny wejść tylko te nazwy miast, wsi, gór, cieków wodnych itp., które posiadają udokumentowany w źródłach historycznych łaciński ekwiwalent. Druga problematyczna kwestia związana jest z lokalizacją nazw w obrębie makrostruktury słownika: czy należy je hasłować wraz z pospolitymi rzeczownikami, czy należy przeznaczyć dlań osobną część opracowania. Zapoznanie się z powszechną praktyką słownikową wskazuje, że w światowej leksykografii klasycznej nazwy własne traktuje się nieco inaczej niż na gruncie słowników języków żywych: znacznie chętniej włącza się je w części leksykalne opracowań (por. np. OLD). W polskich powojennych słownikach łacińskich nazwy własne pojawiają się rzadko ${ }^{7}$, ale ostatni słownik polsko-łaciński wyodrębnia je w postaci ,indeksów” zamieszczonych na końcowych kartach (zob. Winniczuk 1994 (red.): 657-672) i można przedstawić dwie przesłanki za tym, by w projektowanym słowniku tradycję tę kontynuować. Poza bowiem zaznaczeniem ich specyficznego charakteru da to możliwość z jednej strony posegregowania ich ogólnego zbioru w uporządkowane grupy, co zwiększy czytelność i łatwość wyszukiwania, z drugiej opatrzenia każdej z wyróżnionych grup zestawem klasycznych reguł latynizacji nazw w zestawieniu nieujętych, tak by umożliwić użytkownikowi samodzielne tworzenie przybliżonych łacińskich ekwiwalentów onomastycznych ${ }^{8}$.

Nie da się ukryć, że wśród użytkowników pewne frazy cieszą się wyższą frekwencją przekładania niż inne. Ponownie praktyka piszącego te słowa dowodzi, że stosunkowo często pojawiają się zapytania i prośby o tłumaczenie na język łaciński pewnych cytatów z dzieł literatur nowożytnych (np. J.W. Goethe, F. Nietzsche, A. Sapkowski) lub słów wypowiedzianych przez wielkie postaci historyczne (np. J. Piłsudski, Jan Paweł II). Co ciekawe ci, którzy sygnalizują potrzebę tworzenia łacińskich odpowiedników tego typu wypowiedzi, jak wynika z obserwacji, często sami nie dysponują znajomością języka łacińskiego - u podstaw ich działań leży zapewne wysoki status społeczny, jakim wciąż cieszy się łacina, którą postrzega się jako język elitarny, tajemniczy, związany ze sferą sacrum. Temu oczekiwaniu warto wyjść naprzeciw, przygotowując zestawienie najbardziej popularnych fraz przełożonych na łacinę przez specjalistów, tak by w szerszych kręgach mogły funkcjonować ich w miarę ujednolicone, a co

${ }^{7}$ Nawiasem mówiąc, dzieje się tak z dość łatwych do odgadnięcia przyczyn: usunięcie z materiału leksykograficznego zmniejsza ostateczną objętość słownika, ponieważ poza samym ekwiwalentem przekładowym (np. Ulixes 'Odyseusz') muszą towarzyszyć mu niezbędne objaśnienia encyklopedyczne (zob. Plezia (red.) 1959-1979: XXXV), poza tym filolodzy klasyczni od dawna dysponują odrębnymi pracami, które pobocznie spełniają rolę takiego „onomastykonu” (np. P i a n k o, P is z c ze k (red.) 1958-1962).

${ }^{8}$ Wprowadzenie tego postulatu w życie nie byłoby o tyle trudne, że system polonizacji nazw łacińskich i greckich funkcjonuje w skodyfikowanej formie (por. S a far e w i c z 1981), a zatem zadanie polegałoby w dużej mierze na jego „odwróceniu”. 
ważniejsze poprawne gramatycznie wersje. Dzięki wprowadzeniu ich w postaci stosownej partii do słownika polsko-łacińskiego potencjalny chętny stosunkowo łatwo uzyska do nich dostęp, aczkolwiek można brać także pod uwagę wariant, w którym takowe florilegium byłoby wydane w postaci odrębnej całości wydawniczej.

Jako integralna część opracowania, przydatna szczególnie specjalistom, powinien się natomiast pojawić spis odwołań bibliograficznych do najważniejszych pozycji literatury fachowej, które byłyby przydatne w procesie translacji na język łaciński. W jego składzie powinny się znaleźć m.in. adresy dodatkowych opracowań słownikowych (w tym szczególnie słowników starszych i specjalistycznych), najważniejszych tekstów składających się na dorobek polskiej leksykologii klasycznej, a także tych, które podnoszą tematykę stylu określonego autora, dzieła, gatunku czy historycznoliterackiego wycinka czasu.

W swoim czasie referat $R$. Niemca nie znalazł oddźwięku — nie wydaje się, że słownik, który powstał prawie pół wieku po wystąpieniu w PAU (tj. Winniczuk (red.) 1994), starał się przyjąć coś ze sformułowanych podówczas założeń — i dziś jedynym jego szerzej dostrzegalnym echem jest notacja w „Bibliografii słowników polskich” (Grzegorczyk 1967). Piszący te słowa ma cichą nadzieję, że jego pracy uda się nie podzielić tego losu, albowiem kwestia braku dobrego słownika polsko-łacińskiego jest dziś może nie „paląca”, lecz przynajmniej „ważna”. Niektóre z powyżej przedstawionych propozycji mogą się wydawać nieco utopijne, oderwane od realiów tworzenia słowników, a przez to trudne do realizacji lub za daleko odbiegające od ukształtowanej tradycji polskiego słownikarstwa latynistycznego. Mimo to autor powyżej zarysowanego projektu wierzy w możliwość ich urzeczywistnienia.

W następnej kolejności, po zakrojeniu kształtu ogólnego i rozwiązań makrostrukturalnych, powinny zostać ustalone pewne kwestie szczegółowe: sposoby uściślenia przekładu wyrazów funkcyjnych i ekspresywnych, kwestia ilustracji materiałowej, kształt lemmat, miejsce i źródła frazeologii itp. Nie trzeba wspominać, że zająć się tym powinno grono specjalistów, ponieważ jeden badacz, nawet największy, nie byłby w stanie unieść ciężaru zaprojektowania wymagającego tak szerokich działań tworu, nie mówiąc już o jego realizacji. Jeżeli zaś prace zostaną wszczęte, należy pamiętać, by prowadzić je w sposób przemyślany, odpowiedzialny oraz z nieustanną świadomością celu, jakiemu mają one służyć, albowiem to, co powstanie w ich wyniku, wysyci swój odcinek rynku polskiej leksykografii latynistycznej na lata, i to niezależnie od swej jakości. I to stwierdzenie jako jedyne w powyższej pracy nie powinno podlegać dyskusji.

\section{Bibliografia}

A bramowiczówna Z., A p pe 1 W., 2006, Słownik polsko-starogrecki, Toruń. B abecki J., Dąbrowska B., 1978, Słownik lekarski polsko-łaciński, Warszawa.

B ań k o M., 1994, Rzemiosło leksykografa, Wydawca 11-12, s. 20-22.

— 2001, Z pogranicza leksykografii i językoznawstwa. Studia o słowniku jednojęzycznym, Warszawa. 
B a r o n A., 1991, Repertorium Linguae Latinae, Kraków.

B i elik ow ic z A., 1863-1866, Słownik polsko-łaciński, Kraków.

B og u sławski A., 1988, Dwujęzyczny słownik ogólny. Projekt instrukcji z komentarzami, [w:] Studia z polskiej leksykografii współczesnej, red. Z. Saloni, Wrocław, s. 19-65.

Dą brow ska B., 1990, Słownik medyczny polsko-łaciński, Warszawa.

Dubo is J., Dubo is C., 1971, Introduction a la lexicographie: le dictionnaire, Paris.

Grzeg or czyk P., 1967, Index Lexicorum Poloniae. Bibliografia słowników polskich, Warszawa.

K on c ewic z Ł., ${ }^{9} 1929$, Nowy słownik podręczny łacińsko-polski, Lwów.

K o p i a H., 1926, Kieszonkowy słownik języków łacińskiego i polskiego, Berlin.

K orpanty J. (red.), 2001-2003, Słownik łacińsko-polski, Warszawa.

Kruczki ew ic z B. (red.), 1907, Słownik łacińsko-polski, Kraków.

L ew R., 2004, Which dictionary for whom? Receptive use of bilingual, monolingual and semi-bilingual dictionaries by Polish learners of English, Poznań.

Linde-Usiekniewic z J., 2011, Polszczyzna w leksykografii dwujęzycznej — dylematy i postulaty, [w:] Problemy leksykografii. Historia — metodologia — praktyka, red. W. Gruszczyński, L. Polkowska, Kraków, s. 105-121.

Men ge H., 1903, Taschenwörterbuch der lateinischen und deutschen Sprache, Berlin.

N i d a E., 2009, Zasady odpowiedniości, [w:] Współczesne teorie przekładu, red. P. Bukowski, M. Heydel, Kraków, s. 53-69.

N i e m i e c R., 1946, Praca nad słownikiem polsko-łacińskim, Sprawozdania z czynności i posiedzeń Polskiej Akademii Umiejętności XLVI, 9, Kraków, s. 235-237.

OLD — Oxford Latin Dictionary, red. P.G.W. Glare, Oxford 1968-1982.

P i an k o G., P is zczek Z. (red.), 1958-1962, Mała encyklopedia kultury antycznej, Warszawa.

Piotrowski T., 1989, The bilingual dictionary - a manual of translation or a description of lexical semantics, [w:] red. Z. Saloni, Studia z polskiej leksykografii współczesnej III, Białystok, s. 41-52.

— 1994, Z zagadnień leksykografii, Warszawa.

Ple zi a M. (red.), 1959-1979, Słownik łacińsko-polski, Warszawa.

Plezi a M., 2001, Dzieje leksykografii łacińskiej w Polsce, [w:] M. Plezia, Scripta minora. Łacina średniowieczna i Wincenty Kadłubek, Kraków, s. 71-111.

S a fa re w i c z J., 1981, Polska postać łacińskich i greckich starożytnych imion własnych, Język Polski LXI, s. 239-249.

S t á c za k M., 2007, Filologia klasyczna — nauka czy sztuka, [w:] Perspektywy współpracy filologii klasycznej z innymi naukami humanistycznymi. Współczesne metody badania kultury antycznej, red. J. Kwapisz, K. Rzepkowski, W. Sygowska-Pietrzyk, Warszawa, s. 107-113.

S to w a s s e r J.M., 1894, Lateinisch-Deutsches Schulworterbuch, Wien.

To mas zc zy k J., 1979, Dictionaries: users and uses, Glottodidactica XII, s. 103-119.

W ę clew ski Z., ${ }^{3} 1927$, Słownik łacińsko-polski do autorów klasycznych, Lwów.

Winnic zuk L. (red.), 1994, Mały słownik polsko-łaciński, Warszawa.

— ${ }^{13} 2011$, Mały słownik polsko-łaciński, Warszawa.

Wo j a n K., 2013, Z polsko-łacińskiej leksykografii przekładowej. Cz. I. Bibliografia słowników z językiem łacińskim za lata 1964-1989 w układzie chronologicznym, Symbolae Philologorum Posnaniensium Graecae et Latinae XXIII/1, s. 161-191.

Żmigrodzki P., Nowak T., Ulitzka E., 2005, O świadomości leksykograficznej kandydatów na polonistów (na podstawie badań ankietowych), Poradnik Językowy 5, s. 3-21. 


\section{SUMMARY}

\section{Some assumptions for a project of the new Polish-Latin dictionary}

Ke y w ord s: Polish-Latin dictionary, dictionary project, latin lexicography, bilingual lexicography.

Słow a kluc zow e: słownik polsko-łaciński, projekt słownika, leksykografia latynistyczna, leksykografia dwujęzyczna.

This paper focuses on presenting the most important, as it seems, lexicographical assumptions for a new Polish-Latin dictionary, that can be used, if the works on it will ever start. The main contained there questions deals with problem of potential target user (basing on his own experience as a translator, author of paper suggest to aim new dictionary at two kinds of people: professionals (philologists, translators etc.) and non-educated in Latin, and also gives some guidelines, how practically join the needs of both types of users), selection of Polish lexemes for its word-list and possible parts of its macrostructure. Presented assuptions had been work out using the ideas of great Polish lexicographers and also bases on observations of modern languages' dictionaries (and history of Polish lexicography) with special regard for unique character of Latin as a target language in dictionary. Secondary aim of paper is to point out as a problem the lack of adequate dictionary of this kind on Polish lexicographic market. 